\title{
Critical Thinking and Activity Capabilities in Collaborative Learning Using Digital Media through Lesson Study in Zoology Subjects
}

\author{
Agus Haryono ${ }^{1}$, Suatma ${ }^{1}$, Shanty Savitri ${ }^{1}$, Elga Araina ${ }^{1}$ \\ ${ }^{1}$ Department of Biology Education, University of Palangka Raya, \\ Kampus UPR Tunjung Nyaho C-11 Palangka Raya, Kalimantan Tengah, Indonesia \\ e-mail: Agus.Haryono@fkip.upr.ac.id
}

\begin{abstract}
Vertebrate and animal development subjects are covered in Zoology courses in the University of Palangka Raya which is learned in third and fourth semester. These subjects differ in content. Vertebrate course covers animal structure, while animal development course is more about the process of development. Today's learning demands is to develop a critical thinking and build social interaction among students. Collaborative learning incorporating digital media through Lesson Study (LS) was implemented to improve learning outcomes in both subjects. Collaborative learning demands students to be self-minded, cooperative, and able to reveal thoughts mutually to their classmates to be employed for the above-mentioned purpose. The implementation of collaborative learning through LS was done with four cycles of 'Plan, Do, and See' in Vertebrate and Animal Development subjects. These aimed to enhance student's activities and critical thinking capabilities. The studied result showed improvement of activities in problem analysis stage, discussion and delivery of discussion results for zoology courses according to implementation of collaborative learning through LS cycles. Critical thinking capability of students was detected better in both subjects, mainly in the capability of conclusion drawing and presenting discussion results from assignments which were conducted by the aid of digital media. Collaborative learning incorporating digital media through LS could enhance activities and critical thinking capabilities of students.
\end{abstract}

Keywords: Critical thinking; collaborative learning; lesson study

\section{INTRODUCTION}

Vertebrate and Animal Development subjects are covered in Zoology courses in the University of Palangka Raya (UPR). These subjects differ in content. Vertebrate Zoology covers animal structure, while animal development zoology is more about the process of development. Vertebrate and Animal Development courses in UPR are done using direct instruction with a stressing on a lecturer as a learning center. Many researchers feel that this difficulty stems from the passive role the students play in a traditional class [1]. Collaborative learning is an umbrella term for a variety of educational approaches involving joint intellectual effort by students, or students and teachers together. Usually, students are working in groups of two or more, mutually 
searching for understanding, solutions or meanings, or creating a product [2]. Collaboration in the classroom has the potential to elevate the learning of students past the superficial and into the deeper learning that remains for a lifetime [3]. By implementing of collaborative learning in science courses, students may understand the lesson material and also enhance their capability to study critically.

Scheibe and Rogow [4] stated, that media literacy is "to help students develop the habits of inquiry and skills of expression they need to be critical thinkers, effective communicators and active citizens in today's world. Lesson Study is a simple strategy to improve a learning process with collaboration [5]. Lesson study (LS) is a strategy to improve the quality of teaching and learning through studying the teaching and learning processes continuously by empowering teacher's potentials collaboratively and collegially [6]. Lesson study emphasizes student-centered learning and trains high order thinking skills through daily life approach as well as utilizing local materials.

Lesson Study also functions as a continuous professional development. Lesson Study LS is a sustaining classroom-based development strategy for lecturers' professional development by researching collegian's principles and mutual learning to establish learning communities [7]. A lecturer is not only performing teaching but also developing a learning process every day. The development is called jugyo kyenyu as a medium to analyze the learning process by a lecturer together with others [8]. At Univeritas Palangka Raya, LS was developed since 2010 until now, especially at the Faculty of Teacher Training and Education. The implementation collaborative learning through LS with the application of digital media could be done to improve capability of activities of students in Zoological course.

\section{IMPLEMENTATION OF LESSON STUDY}

The subjects as data sources were students from biology education study program who were taking zoology course during the even semester. Zoology course containing Animal Development and Vertebrate were given at the third and fourth semester stated in the syllabi of biology education program course. Study method for the implementation of collaborative learning through LS on zoology courses was performed in four cycles in each course. Every cycle of LS consisted of 'Plan, Do, and See'. It started from syllabi study, learning execution, and reflection [9]. The collaborative team consisted of one Model Lecturer (ML) and three observers with similar skills. During the 'Plan' stage, the lecturers with three observers to create a Lesson Plan (LP) of collaborative learning model and student working sheets as an observation sheet. In 'Do' stage, collaborative learning observation was implemented in the class. The ML conducted teaching in class as planned in LP of collaborative learning model. All observers studied the student learning process in depth based on observation sheets, observation focuses on the interaction of teachers and students' responses [10]. Instrument to collect data was observation sheet toward activities and critical thinking of students [11]. Other collaborators acted as observers. In 'See' stage or reflection, the ML and other observer's revealed facts found during the lecturing and discussed for improvement. The resulting data on activity and critical thinking from observer were analyzed descriptive qualitatively. 


\section{RESULT AND DISCUSSION}

Observation results of the students' activities during collaborative learning through LS using digital media on Zoology courses can be seen in Table I. Based on Table I, during the learning process or 'Do' I, II, III, and IV, the activity of students increased. In the first open lesson, the capability of students to explain the connection of concepts was poor (a), classroom discussion was not optimal since many students were still passive and never asked or argued (b), students never used the lecturer as a supervisor or companion during learning process because they used to be in a centralistic learning process (c), Student interactions during lecturing were adequate (d). The capability of students to present the group achievement was optimal in animal development course, and (e) Student maintained their activity results adequately (f)

TABLE I. STUDENT ACTIVITY IN COLLABORATIVE LEARNING USING DIGITAL MEDIA

\begin{tabular}{|c|c|c|c|c|c|}
\hline \multirow[t]{2}{*}{ Course } & \multirow[t]{2}{*}{ Student's Learning activity } & \multicolumn{4}{|c|}{$\begin{array}{c}\text { Results of Observer } \\
\text { Assesment on LS Stages }\end{array}$} \\
\hline & & $\mathrm{I}$ & II & III & IV \\
\hline \multirow[t]{6}{*}{ Vertebrate } & a) explaining the concept & 2.75 & 3.75 & 3.75 & 3.75 \\
\hline & b) doing classroom discussion & 3.00 & 3.50 & 3.75 & 4.00 \\
\hline & $\begin{array}{l}\text { c) using lecturer as a supervisor or } \\
\text { companion during learning process }\end{array}$ & 2.00 & 2.50 & 3.25 & 3.75 \\
\hline & d) interaction during lectures & 2.50 & 3.25 & 3.75 & 3.75 \\
\hline & e) presentation in the group & 2.00 & 2.75 & 3.00 & 3.00 \\
\hline & f) maintaining their activity results & 2.75 & 3.00 & 3.50 & 3.75 \\
\hline \multirow{6}{*}{$\begin{array}{l}\text { Animal } \\
\text { Development }\end{array}$} & a) explaining the concept & 2.75 & 3.50 & 3.75 & 3.75 \\
\hline & b) doing classroom discussion & 3.00 & 3.00 & 4.00 & 4.00 \\
\hline & $\begin{array}{l}\text { c) using lecturer as a supervisor or } \\
\text { companion during the learning } \\
\text { process }\end{array}$ & 2.00 & 2.50 & 3.00 & 3.50 \\
\hline & d) interaction during lectures & 2.50 & 3.00 & 3.50 & 3.75 \\
\hline & e) presentation in the group & 3.00 & 3.75 & 4.00 & 4.00 \\
\hline & f) maintaining their activity results & 2.75 & 3.25 & 3.50 & 3.75 \\
\hline
\end{tabular}

Note : 0-1.9 : poor, 2.0 -2.9: adequate, 3.0-3.9, good, 4.0: excellent

During stage II of the open lesson, it was recognized that the capability of students to explain the connection of concepts was improving (a), Classroom discussion was running optimally, many students started to be active (b), students already took advantage of having lecturer as supervisor and companion during the learning process (c). Student interactions during learning process were running adequately (d). In 'Do' stage from the first open lesson, the student activities were seen clearly during the discussions, which be categorized as excellent (e), Then during the presentation of student group achievement in animal development course was optimal in stage III and IV. The activity changed in connection with the syntax of collaboration, which was more active during discussion and presentation of discussion results.

In 'Do' stage of the third and fourth open lessons, all student activities observed have reached maximum scores on problem solving, discussion, presentation, and giving an opinion, which could be categorized as very satisfying. Based on stages of the application of LS, that is, during the learning process, as a result of the changes of learning model from direct instruction students became collaborative; these study stages 
of LS helped the model lecturer a lot to perfect the Lesson Plan which was created collectively amongst lecturers of related subjects [12]. Collaborative learning is an umbrella term for a variety of educational approaches involving joint intellectual effort by students, or students and teachers together. Usually, students are working in groups of two or more, mutually searching for understanding, solutions or meanings, or creating a product [13].

The study results of student activities showed that collaborative learning model was able to activate students to follow the learning process well. Besides, the application of collaborative learning could centralize the learning process to students instead of to lecturers. It was evident from the increasing student role during the learning process. The implementation of LS by the subject of Chemistry course with cooperative learning model in a small group and presentation could improve communication skills in the learning process [14].

TABLE II. THE IMPLEMENTATION OF LESSON STUDY BY APPLYING COLLABORATIVE LEARNING TOWARD THE CRITICAL THINKING ZOOLOGY COURSES

\begin{tabular}{llcccc}
\hline Course & \multicolumn{1}{c}{ Students Critical Thinking } & \multicolumn{3}{c}{$\begin{array}{c}\text { Result of Observer } \\
\text { Assesment on Lesson Study } \\
\end{array}$} & \multicolumn{3}{c}{ Stages } \\
\cline { 3 - 6 } & & I & II & III & IV \\
& Asking the problem & 2.75 & 3.75 & 3.50 & 3.75 \\
Vertebrate & Aims of learning & 3.00 & 3.50 & 3.50 & 3.75 \\
& information & 2.00 & 2.50 & 3.25 & 3.50 \\
& concept & 2.50 & 3.25 & 3.50 & 3.75 \\
& interpreting and making a & 2.00 & 3.00 & 3.00 & 3.50 \\
& conclusion & & & & \\
\hline Animal Development & Asking the problem & 2.75 & 3.75 & 3.75 & 3.75 \\
& Aims of learning & 3.00 & 3.75 & 4.00 & 4.00 \\
& Information & 2.00 & 2.50 & 3.50 & 3.75 \\
& concept & 2.50 & 3.25 & 3.75 & 4.00 \\
& interpreting and making a & 2.00 & 3.00 & 4.00 & 4.00 \\
& conclusion & & & & \\
\hline
\end{tabular}

Note : 0-1.9 : poor, 2.0 -2.9: adequate, 3.0-3.9, good, 4.0: excellent

Elements to think critically used in this study were adopted from Inch with only five elements of critical thinking, namely asking the problem (a), aims (b), information (c), concept (d), interpretation and making the conclusion (e). The observation results on the critical thinking capability by the application of collaborative learning for zoology topics with modified critical thinking capability from each element are listed in Table II.

Based on the studied results, it was known that the student's capability to describe the discussion results was getting better as a result of the application of collaborative learning model which was implemented in LS. Similar trend was also shown in, both Zoological Vertebrate and Animal Development subjects, i.e. to understand the aims, interpreting and making a conclusion. The observation results on the critical thinking capability were reaching maximum on the implementation of LS at the Animal Development subject. This is in line with LS for biology course with collaborative model [15]. Lesson study provided experience for students as an effective effort to enhance the learning quality by lecturer and also student learning activities. This is 
based on the development of Lesson Study as a result professional "sharing" of knowledge on teaching practice and result of related subject lecturers. Students collaborate with each other through discussion and mutual learning to develop critical thinking capability [16]. Students joining lecture LS have learning quality not only to understand the concepts being taught, but also have other competency to be developed as a life skill [17]. The learning focus of LS is mainly for student activities based on the real experiences in the classroom, then LS is able to be used as a base for the development of learning cooperatively by placing a teacher or lecturer as the researcher of the learning process [18].

In this study, the implementation of collaborative learning model through LS with four cycles could enhance the collaboration activities amongst student. Lecturer activities during 'Plan' were agreed with the corresponding lecturers. 'Do' during open lesson and 'See' were followed more by the observer from zoology related subjects. By the increase of the observer's responses during open lesson or 'See' activities toward the learning process, then the positive suggestions and improvement were getting better. This provided chances for the model lecturer to improve in the subsequent lessons. Collaborative learning model implemented with LS could form collegiality and collaboration among lecturers from closed-related subjects and could enhance to make lesson plan better. Therefore, implementation lesson plan of collaborative learning model as a revision from 4 times 'See' cycle of LS could enhance activities and critical thinking capabilities of students.

\section{CONCLUSION}

Collaborative learning implemented with Lesson Study could enhance students' presentation activities in the group, while their critical thinking capabilities also improved as shown in the indicator of understanding the objectives and in interpreting and drawing conclusion.

\section{ACKNOWLEDGEMENTS}

The authors acknowledge all lecturers from the University of Palangka Raya who teach zoology related subjects for their useful collaborative discussion during 'Plan, Do and See' cycles. Thanks are extended to the Director of BELMAWA DIKTI for financial support by providing Grant for Lesson Study in Higher Education Institution from 2010 until 2012, and commitment of FKIP UPR to conduct Lesson Study until now.

\section{REFERENCES}

[1] Zoller, U. 2000. "Teaching Tomorrow's College Science Courses-Are We Getting It Right?" J.f College Science Teaching, 29, 6:409-414.

[2] Smith, B.L and McGregor, J.T. 1992. "What is collaborative learning: A sourcebook for higher education". University Park, PA : National Center on Postsecondary Teaching, Learning and Assessment (NCTLA).9-22.

[3] Reed, Z.A. "Collaborative Learning in the Classroom". Faculty Excellence, United States Military Academy, West Point, NY, 2014. 
[4] Scheibe, C and Rogow, F. 2008. "Basic Ways to Integrate Media Literacy and Critical Thinking into Any Curriculum" (3rd Ed.). www.ithaca.edu/looksharp

[5] Catherine, L. 2002. "Lesson Study: A Handbook of Teacher-Led Instructional Change". Research for Better Schools, Philadelphia,Inc.

[6] Lewis, C. 2002. "Lesson Study: A Handbook of TeacherLed Instructional Change. Research for Better Schools", Philadelphia,Inc

[7] Syamsuri, I \& Ibrohim. 2011. “Lesson Study (Studi Pembelajaran)”. Penerbit UM Press, Malang.,pp.19-20.

[8] Susilo, H, Husnul, C., Ridwan, J., Jumiati, Yuyun, D., Sari, Sunarjo. 2011. "Lesson Study". Penerbit UM Press, Malang.,pp. 3-4.

[9] Ibrahim, 2010. “ Panduan Pelaksanaan Lesson Study di KKG” Universitas Negri Malang http://www.slideshare.net/haikalmoch/panduanpelaksanaan-lesson-study

[10] Hidayat, A. \& Hendayana, S. 2013. "Developing tools for analyzing of classroom interaction: Does it student-centered or teacher-centered lesson". Bandung: Seminar internasional MSCEIS. UPI.

[11] Inch, E .S. 2006. "Critical Thinking and Communication: The Use of Reason in Argument." fifth. Ed. Boston: Pearson Education, Inc.

[12] Suyanto, A. 2011. "Penerapan Lesson Study di dalam Lesson Study Untuk Meningkatkan Kemampuan Kajian Kritis Mahasiswa Pada Pembelajaran Sains”. Prosiding Seminar Nasional LS IV. Malang, Indonesia., pp. 462-468.

[13] Lewis C., Perry, and Murata. 2006. "How should research contribute to instructional improvement? the case of Lesso n study". Educational research 35 (3) : 3-114.

[14] Suherman, 2011.'Lesson Study Untuk Meningkatkan KAMI (Kreativitas, Aktivitas, Motivasi, dan Inovasi) Pada Pembelajaran Kimia Fisik", Prosiding Seminar Nasional LS IV, Malang, Indonesia.,pp. 131-136.

[15] Warianto, C. 2011. Penerapan Lesson Study Berbasis Sekolah Di SMP Tunas Agro dalam Mengembangkan Pembelajaran Dosen Mengaktifkan Siswa Belajar". Prosiding Seminar Nasional LS IV, Malang, Indonesia,. 194-206.

[16] Masaaki, S. 2012. Dialog dan Kolaborasi di Sekolah Menengah pertama Praktek " Learning Community". PELITA. Peningkatan Kualitas SMP/MTs Kerjasama Teknis DEPDIKNAS./DEPAG-JICA.,pp.24-25.

[17] Hartono.2011. "Model Pembelajaran Kooperatif Untuk Meningkatkan Keterampilan Komunikasi Mahasiswa". Prosiding Seminar Nasional LS IV, Malang. Indonesia. 432-437.

[18] Pangestu, A. A., Siti, Z, Balqis. 2011. "Penerapan Panduan Metode Numbered Heads Together dan Student Teams Achievement Divisions Untuk Meningkatkan Kemampuan Berpikir Kritis dan Hasil Belajar Kognitif Siswa Kelas VIII A SMP Negeri 13”. Prosiding Seminar Nasional LS IV, Malang, Indonesia.,pp. 124-134. 